\title{
HEALTH PHYSICS Enrollments and Degrees Decreased at all Levels in 1997
}

\section{SURVEY UNIVERSE}

The "Health Physics Enrollments and Degrees, 1997" survey consisted of 51 institutions offering a major in health physics/radiation protection or radiation health, or an option program equivalent to a major (for example, in radiobiology or biophysics) that prepare the graduates to perform as health physicists. Of the 51 programs, 1 was reported as inactive, and 5 programs have been suspended; 1 reported last degrees in 1996, 2 reported last degrees in 1997, and 2 programs were allowing students to complete their degrees. The data for 5 programs were estimated.

\section{UNDERGRADUATE ENROLLMENTS AND DEGREES}

The total number of undergraduate enrollments decreased from 237 to 183 students, or by 23 percent from 1996. The number of full-time students decreased from 115 to 90. (Figure 1.) As in 1996, the decrease was attributed to the suspended programs not accepting new enrollments, and a general decline among all programs. The majority of the students were enrolled in the health physics/radiation protection radiation health major (79 percent), followed by engineering or basic sciences option programs (11 percent).

Figure 1. Health Physics Undergraduate Enrollments and Degrees, 1987-1997

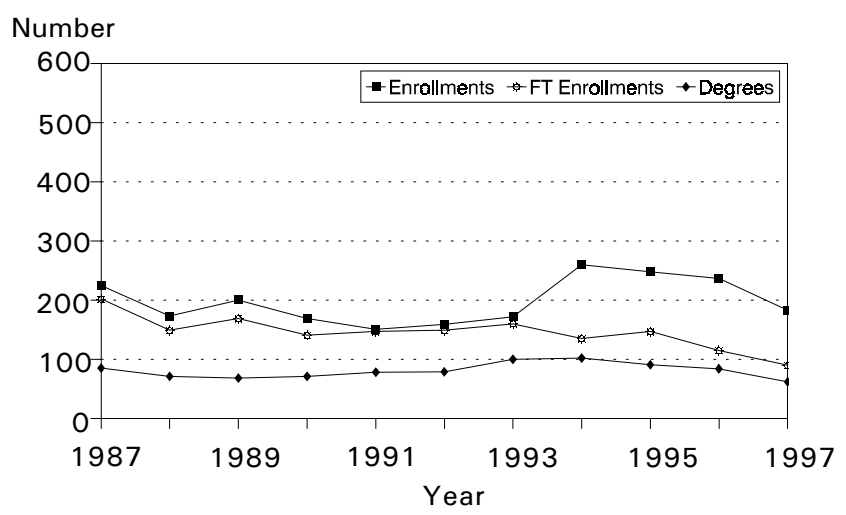

Undergraduate $=$ Junior and Senior Level. Source: U.S. Department of Energy.
Undergraduate degrees decreased from 84 to 62 students in 1997. As with enrollments, most of the degrees were awarded within the health physics/ radiation protection or radiation health major (79 percent), while health physics/radiation protection engineering programs accounted for 15 percent of the undergraduates.

\section{MASTER'S ENROLLMENTS AND DEGREES}

In 1997, the number of master's enrollments decreased from 460 students to 413 , or by 10 percent, continuing the downward trend since 1993. (Figure 2.)

Figure 2. Health Physics Master's Enrollments and Degrees, 1987-1997

Number

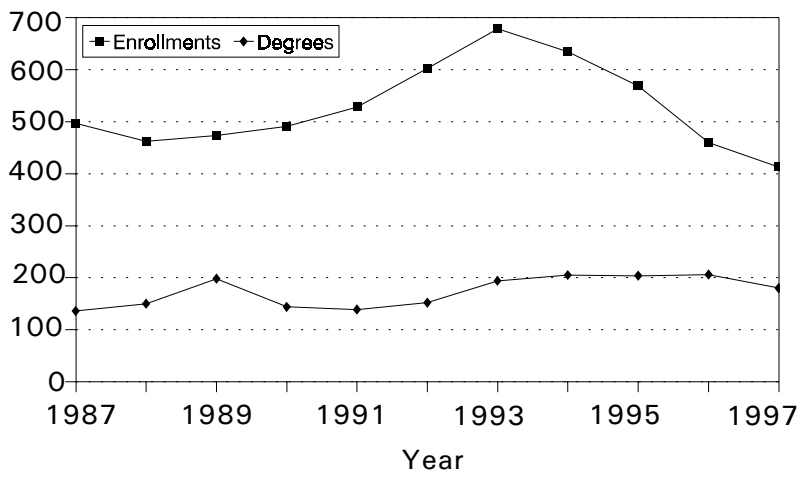

Source: U.S. Department of Energy.

The number of full-time and part-time students were 234 and 179, respectively. Sixty-four percent of the students were enrolled in the health physics/radiation protection or radiation health programs. Among the option programs, engineering or basic sciences enrolled 16 percent, and medical or radiological physics programs accounted for 15 percent of the students.

The number of master's degrees decreased from 206 to 180 students, or by 13 percent from 1996 . The majority of the degrees were awarded within the health physics/radiation protection or radiation health major (63 percent or 114 students), followed by medical or radiological physics (21 percent) and engineering or basic sciences programs (13 percent). 


\section{DOCTORAL ENROLLMENTS AND DEGREES}

Doctoral enrollments decreased in 1997 by 7 percent, or from 223 students in 1996 to 208 (175 fulltime and 33 part-time). (Figure 3.) Forty-six percent (87 full-time and 9 part-time students) were enrolled in the medical or radiological physics option programs, while health physics/radiation protection radiation health programs enrolled 35 percent ( 57 full-time and 16 parttime).

Figure 3. Health Physics Doctoral Enrollments and Degrees, 1987-1997

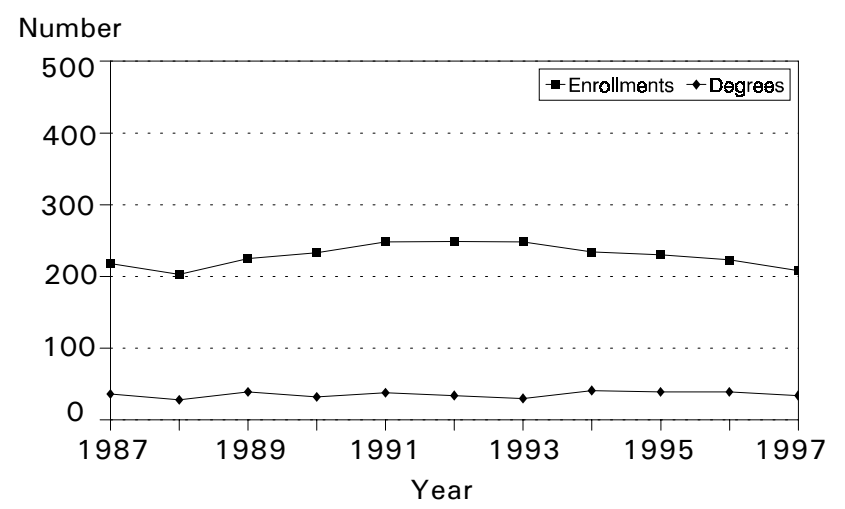

Source: U.S. Department of Energy.

Doctoral degrees decreased by 5 students, from 39 in 1996 to 34, or by 13 percent. As with enrollments the highest number of students received their degrees within the medical or radiological physics option programs (47 percent or 16 students), followed by the health physics/radiation protection or radiation health programs (26 percent or 9 students).

\section{EMPLOYMENT OR POSTGRADUATION PLANS}

Of the known employment or postgraduation plans of the new graduates, 34 percent of the bachelor's were continuing study for a higher degree, 26 percent of the students went to work in nuclear utilities, and 11 percent were still seeking employment. (Table 1.) Twenty-two percent of the master's were continuing study, 15 percent went to work in medical facilities, and 10 percent were working at DOE contractor facilities (M\&Os). For the new doctorates, 32 percent went to work in academia, and continued study and medical facilities represented 15 percent each.
Table 1. Employment or Postgraduation Plans of Health Physics Graduates by Degree Level, 1997 (Percent Distribution)

\begin{tabular}{lccc}
\multicolumn{1}{c}{$\begin{array}{c}\text { Employment or } \\
\text { Postgraduation Plans }\end{array}$} & B.S. & M.S. & Ph.D. \\
\hline Continued study & $34 \%$ & $22 \%$ & $15 \%$ \\
U.S. academic employ. & 5 & 5 & 32 \\
Federal gov. employ. & 2 & 6 & 0 \\
DOE contractors (M\&Os) & 6 & 10 & 8 \\
State and local gov. employ. & 0 & 7 & 0 \\
Medical facilities employ. & 2 & 15 & 15 \\
U.S. nuclear utility employ. & 26 & 4 & 0 \\
U.S. other industrial employ. & 5 & 6 & 8 \\
Employ. with foreign employer & 0 & 2 & 3 \\
U.S. military service & 5 & 4 & 6 \\
Other/Unknown & 5 & 15 & 12 \\
Still seeking employment & 11 & 3 & 0 \\
TOTALS & $100 \%$ & $100 \%$ & $100 \%$ \\
NOTE: Percentages are rounded to nearest whole number. & \\
Source: U.S. Department of Energy. &
\end{tabular}

Two foreign nationals received bachelor's degrees. Master's degrees awarded to foreign nationals decreased by 2 , from 23 in 1996 to 21 , and doctorate degrees decreased from 13 to 9 students. The two bachelor's were reported as still seeking employment, and 9 of the master's were continuing study for a higher degree. Of the foreign national doctorates, 3 were continuing study, 2 were working in medical facilities, and 1 went to work for a foreign employer. (See Table 2 for percent distribution of foreign nationals.)

Degrees awarded to minorities (excluding foreign nationals) in health physics programs remained low in the 1 to 6 percent range, with Hispanic American master's degree recipients increasing from 6 in 1996 to 10 students. (NOTE: In 1997, ethnicity data were collected for degrees only.)

Table 2. Percentage of Health Physics Degrees Awarded to Foreign Nationals, 1993-1997

\begin{tabular}{cccc} 
Year & B.S. & M.S. & Ph.D. \\
\hline & & & \\
1993 & 1 & 16 & 53 \\
1994 & 2 & 15 & 46 \\
1995 & 2 & 17 & 51 \\
1996 & 0 & 11 & 26 \\
1997 & 3 & 12 & 26
\end{tabular}

Source: U.S. Department of Energy. 
Table 3. Health Physics Enrollments and Degrees, by State and Institution, 1997

\begin{tabular}{|c|c|c|c|c|c|c|c|}
\hline & & & ollments & & & Degree & \\
\hline State & Institution & Undergraduate & Master's & Doctoral & B.S. & M.S. & Ph.D. \\
\hline ARIZONA & Arizona State University* & 1 & - & - & - & - & 1 \\
\hline ARKANSAS & Univ. of Arkansas for Med. Sci. ${ }^{1}$ & - & - & - & - & 1 & - \\
\hline CALIFORNIA & San Diego State University & - & 10 & - & - & 5 & - \\
\hline & San Jose State University** & - & 27 & - & - & 4 & - \\
\hline & University of California, Irvine & - & - & 6 & - & - & - \\
\hline & University of California, Los Angeles & - & 2 & 43 & - & 3 & 3 \\
\hline & University of Southern California** & - & 1 & 3 & - & - & - \\
\hline COLORADO & Colorado State University & - & 5 & 5 & - & 12 & 2 \\
\hline & National Technological University & - & 11 & - & - & - & - \\
\hline & University of Colorado HSC** & - & 5 & - & - & 2 & - \\
\hline DIST. OF COLUMBIA & Georgetown University & - & 22 & - & - & 3 & - \\
\hline FLORIDA & Florida A\&M University & - & 3 & - & - & - & - \\
\hline & University of Florida, Gainesville ${ }^{2}$ & - & 22 & 7 & 2 & 11 & 2 \\
\hline GEORGIA & Georgia Institute of Technology & - & 29 & - & - & 16 & - \\
\hline IDAHO & Idaho State University & 18 & 26 & 2 & - & 2 & - \\
\hline ILLINOIS & Rush University & - & 1 & 8 & - & 1 & 1 \\
\hline & University of Illinois, Urbana & - & 2 & 3 & - & 4 & - \\
\hline INDIANA & Purdue University & 17 & 4 & 3 & 8 & 1 & 1 \\
\hline KENTUCKY & University of Kentucky & - & 10 & - & - & 6 & - \\
\hline LOUISIANA & Louisiana State University & - & 10 & - & - & 8 & - \\
\hline MAINE & University of Maine & 2 & - & 1 & - & - & - \\
\hline MARYLAND & Johns Hopkins Sch. of Public Health & - & 1 & 2 & - & - & 2 \\
\hline MASSACHUSETTS & Harvard School of Public Health & - & - & 3 & - & 1 & 4 \\
\hline & Massachusetts Institute of Technology & - & 9 & 4 & - & 1 & - \\
\hline & University of Massachusetts Lowell & 6 & 32 & 16 & 6 & 11 & 4 \\
\hline MICHIGAN & University of Michigan ${ }^{3}$ & - & 21 & 2 & - & 11 & 1 \\
\hline MISSOURI & University of Missouri, Columbia & - & 6 & 14 & - & 8 & 2 \\
\hline & University of Missouri, Rolla & 4 & 1 & 1 & 2 & - & - \\
\hline NEVADA & University of Nevada & 8 & 8 & - & - & - & - \\
\hline NEW JERSEY & Rutgers University* & - & 10 & 7 & - & 2 & 2 \\
\hline & Thomas Edison State College & 80 & - & - & 16 & - & - \\
\hline NEW MEXICO & University of New Mexico & - & 10 & - & - & 3 & - \\
\hline NEW YORK & New York Univ. Medical Center & Inactive & - & - & - & - & - \\
\hline & State Univ. of New York, Buffalo ${ }^{1}$ & - & - & - & 4 & 5 & - \\
\hline NORTH CAROLINA & East Carolina University & 2 & - & - & - & - & - \\
\hline & Univ. of North Carolina, Chapel Hill & - & 4 & 1 & - & 4 & - \\
\hline OHIO & Medical College of Ohio & - & 8 & 8 & - & - & 1 \\
\hline & University of Cincinnati & - & 14 & - & - & 11 & - \\
\hline & Ohio State University & - & 7 & 6 & - & 5 & 1 \\
\hline OREGON & Oregon State University & 15 & 9 & 3 & 8 & 8 & - \\
\hline PENNSYLVANIA & Bloomsburg Univ. of Pennsylvania & 3 & - & - & 4 & - & - \\
\hline & Dickinson College & 1 & & & & & \\
\hline & University of Pittsburgh & - & 3 & 6 & - & - & - \\
\hline SOUTH CAROLINA & Clemson University & - & 15 & 6 & - & 7 & - \\
\hline & Francis Marion College & 6 & - & - & 2 & - & - \\
\hline TENNESSEE & University of Tennessee, Knoxville & 10 & 15 & 9 & 7 & 4 & 2 \\
\hline TEXAS & Texas A\&M University & 10 & 17 & 11 & 3 & 6 & - \\
\hline UTAH & University of Utah** & - & 2 & 8 & - & 1 & 2 \\
\hline WASHINGTON & Washington State Univ., Tri-Cities & - & 5 & - & - & 2 & - \\
\hline WISCONSIN & University of Wisconsin, Madison & - & 26 & 20 & - & 11 & 3 \\
\hline TOTALS & & 183 & 413 & 208 & 62 & 180 & 34 \\
\hline
\end{tabular}

*Program suspended; students are being allowed to complete their degrees. ** Estimated.

NOTES: ${ }^{1}$ The programs at the University of Arkansas for Medical Science and the State University of New York, Buffalo are suspended; last degrees awarded in 1997.

${ }^{2}$ The undergraduate program at the University of Florida, Gainesville, was revised in 1997. All health physics students are now being classified as nuclear engineers.

${ }^{3}$ The number of health physics students within the environmental and industrial health department at the University of Michigan was estimated and included with the radiological health program numbers above. 
This report is based on work performed under Contract Number DE-AC05-OR00033 between the U.S. Department of Energy and Oak Ridge Associated Universities.

All opinions expressed in this report are the authors' and do not necessarily reflect policies and views of the U.S. Department of Energy or the Oak Ridge Institute for Science and Education.

Additional survey information, providing details by individual schools and by type of program, is available from:

Oak Ridge Institute for Science and Education

Science and Engineering Education

Analysis and Evaluation Programs

P.O. Box 117

Oak Ridge, TN 37831-0117

Oak Ridge Institute for Science and Education Analysis and Evaluation Programs, MS 36

P.O. Box 117

Oak Ridge, TN 37831-0117

Manpower Brief \# 43 